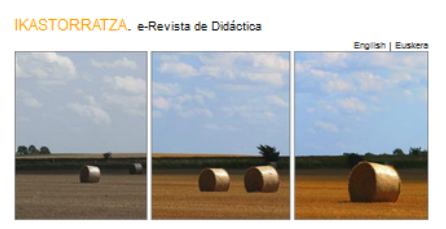

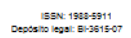

Inicio, Sobre nosotros, Publicacionesl, Participe

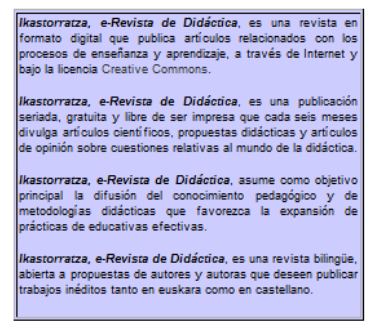

\section{IKASTORRATZA. Didaktikarako e-aldizkaria}

\author{
IKASTORRATZA. e-journal on Didactics
}

ISSN: 1988-5911 (Online) Journal homepage: http://www.ehu.eus/ikastorratza/

\title{
Konduktismo eta konstruktibismotik abiatuz Haur Hezkuntzako ikasgeletako praktika hezigarrien azterketa
}

\author{
IKASTORRATZA. e-Revista de \\ Didáctica
}

Ana Carbajo Diaz anacarbajo1996@gmail.com

Nahia Idoiaga Mondragon nahia.idoiaga@ehu.eus

Maitane Belasko Txertudi maitane.belasko@ehu.eus

To cite this article:

Ana Carbajo, A.; Idoiaga, N \& Belasko, M. (2020). Konduktismo eta konstruktibismotik abiatuz Haur Hezkuntzako ikasgeletako praktika hezigarrien azterketa. IKASTORRATZA. e-Revista de Didáctica, 25, 151-178. DOI: 10.37261/25_alea/6

To link to this article:

https://doi.org/10.37261/25_alea/6

Published online: 31 october 2020 


\title{
Konduktismo eta konstruktibismotik abiatuz Haur Hezkuntzako ikasgeletako praktika hezigarrien azterketa
}

\author{
Ana Carbajo Diaz ${ }^{1}$, Nahia Idoiaga Mondragon² eta Maitane Belasko Txertudi ${ }^{3}$ \\ ${ }^{1}$ Haur Hezkuntzan graduatua. \\ anacarbajo1996@gmail.com \\ ${ }^{2}$ Bilakaera eta Hezkuntzaren Psikologia Saila. \\ Universidad del País Vasco/Euskal Herriko Unibertsitatea (UPV/EHU) \\ nahia.idoiaga@ehu.eus \\ ${ }^{3}$ Didaktika eta Eskola Antolakuntza saila. \\ Universidad del País Vasco/Euskal Herriko Unibertsitatea (UPV/EHU) \\ maitane.belasko@ehu.eus
}

\section{Laburpena}

XX. mendeko lehen hamarkadetan sortutako korronteak izan arren konduktismoak eta konstruktibismoak egungo hezkuntza metodologien oinarri izaten jarraitzen dute. Izan ere, hezkuntza-sistemaren egungo erronketako bat ikasgeletan konstruktibismoa finkatzea da, horrela ikasleak izango bailirateke beren hezkuntza-prozesuaren arduradun eta beren ezagutzen eraikitzaile. Lan honen helburua haur hezkuntzako irakasleen artean gehien erabiltzen diren hezkuntza teknikak zein diren eta zein metodologia joeratan oinarritzen diren aztertzea da. Era berean, kontuan hartuko da irakasleak jardunean duten eskola motak (publiko edo pribatu) eta lanean diharduten urteek tekniken erabilerari eragiten dioten. Horretarako jardunean dauden 117 irakasleri beren beregi sortutako galdetegia pasa zitzaien. Emaitzek adierazi zutenez zigorren erabilpena baxuagoa den arren errefortzuen eta baliabide konstruktibisten erabilera (batez ere, aldamiaia, espiral curriculuma eta ikasleen interesetik abiatzea) altua da. Ondorioz, gehiegizko justifikazioaren efektuari buruz hausnartzeko beharra erdiesten da eredu eta baliabide konstruktibisten bidean jarraitzearekin bat.

Hitz gakoak: Konduktismoa, Konstruktibismoa, Haur Hezkuntza, Irakasleak, Errefortzuak, Jokabidea. 


\section{Resumen}

El conductismo y el constructivismo siguen siendo la base de las metodologías educativas actuales, a pesar de ser corrientes surgidas en las primeras décadas del siglo XX. De hecho, uno de los retos contemporáneos del sistema educativo se basa en afianzar el constructivismo en las aulas, lo que permitiría convertir al alumnado en responsable de su proceso educativo y en constructor de sus conocimientos. El objetivo de este trabajo será analizar qué técnicas educativas son las más utilizadas entre el profesorado de educación infantil y en qué corrientes metodológicas se basan mayormente. Asimismo, se tendrá en cuenta si el tipo de escuela en el que ejercen los y las docentes (público o privada) y los años de profesión afectan a la utilización de las diferentes técnicas. Para ello, se pasó a 117 docentes en activo un cuestionario ad hoc. Los resultados indicaron que aunque la utilización de los castigos es inferior, el nivel de utilización de refuerzos y recursos constructivistas (sobre todo el andamiaje, el currículo en espiral y partir del interés del alumnado) es alto. En consecuencia, se ve necesario el reflexionar sobre el efecto de sobre-justificación, junto con seguir promoviendo modelos y recursos constructivistas.

Palabras clave: Conductismo, Constructivismo, Educación Infantil, Profesorado, Refuerzo, Conducta. 


\begin{abstract}
Behaviorism and constructivism continue to be the basis of current educational methodologies, despite being commonplace in the first decades of the twentieth century. In fact, one of the contemporary challenges of the educational system is based on strengthening constructivism in the classroom, which would allow students to become responsible for their educational process and build their knowledge. The aim of this paper will be to analyse which educational techniques are the most used among early childhood education teachers and on which methodological currents they are mostly based. It will also take into account whether the type of school in which teachers work and their years of experience affect the use of those techniques. To this end, an ad hoc questionnaire was sent to 117 active teachers. The results indicated that, although the use of punishments is lower, the level of use of reinforcements and constructivist resources (above all, the scaffolding, the spiral curriculum, and starting from the interest of the students) is high. Consequently, it is necessary to reflect on the effect of overjustification, together with continuing to promote constructivist models and resources.
\end{abstract}

Key words: Behaviorism, Constructivism, Infant Education, Teachers, Reinforcement, Conduct. 


\section{Sarrera}

Hezkuntzaren psikologiak, diziplina zientifiko bezala, irakasleentzat euren praktikarako garrantzitsua den jardun pedagogikoen oinarria osatzen du, psikologo zein pedagogoek irakaste eta ikaste prozesuen marko teorikoa azaltzeko sortua dena. Izan ere, hezkuntzaren psikologiak hezkuntzaren printzipio, azalpen eta metodoak biltzen ditu bere jakintzen baitan (Beltrán eta Bueno, 1995; Castejón, González, Gilar eta Miñano, 2010). XX. mendean, hezkuntza psikologikoaren baitan oraindik oihartzun handia duten korronte psikologikoak garatu ziren, beraien artean nagusiak, behaviorismoa edo konduktismoa eta konstruktibismoa izanik (Bueno eta Castanedo, 1998).

\subsection{Zer da konduktismoa?}

XX. mendearen hasieran, Watsonek psikologiaren helburu tradizionala aldatzea proposatu zuen, eta honek konduktismoaren hastapena bultzatu zuen. Izan ere, korronte berri honek izakien jokabidearen analisi esperimentala azaltzea aldarrikatu zuen (Pellón, 2013). Horrela, "El manifiesto conductista” liburuan behaviorismoa behagarriak diren jarduerak azaltzen dituen sistema zientifiko eta logikoa bezala definitu zen (Watson, 1913; Pellón, 2013tik aipatua). Bestalde, estimulu eta erantzunen artean ematen diren konexioetan oinarritzen den korronte honetan (Coll, 1998; Gil, 2013), jokabide aldaketak azaltzeko, hiru ikuspegi bereizten dira: klasikoa (Watson eta Paulov autoreek landua), operantea (Thorndike eta Skinner autoreek landua) eta neokonduktismoa (Bandurak landua) (Castejón et al., 2010; Coll, Palacios eta Marchesi, 2002).

Baldintzapen klasikoa ikaskuntza prozesuan ematen den mekanismorik oinarrizkoena da (González-Pienda, 2008). Pavlov-ek txakurrekin egindako ikerketa famatuetan ikuspegi honen oinarriak finkatu zituen (Sanz, 2010). Pavlov eta Watsonek ikaskuntza asoziazioan oinarritzen zela aldarrikatu zuten, funtsean bi estimulu batera agertzen direnean hauen arteko elkarrekintzaren ondorioz bien arteko konexioa emango delako. Ondorioz, estimulu bat agertzean erantzuna sortuko du (Sanz, 2010). Watsonek bere doktrina konduktista garatu zuenean jokabideen ikerketa enpirikoan eta interpretazioan oinarritu zen hiru fenomeno proposatuaz: orokortzea (estimulu baldintzatuen antzeko estimuluei ematen zaion erantzun baldintzatua da), diskriminazioa (estimulu baldintzatuen antzeko estimuluei erantzun baldintzatua ez ematea da) eta iraungitzea (baldintzatutako estimuluari erantzun baldintzaturik ez ematea da) (Castejón et al., 2010; González-Pienda, 2008; Fonseca eta Niñón, 2011). 
Baldintzapen operantean Skinner eta Thorndikeren lanak nabarmentzen dira, norbanakoak ikasten dituen nahitako erantzunetan oinarritu zutelarik beraien ikerkuntza (Castejón et al., 2010; Coll et al., 2002). Skinnerek ikertutako errefortzu programagatik eta Thorndikek garatutako baldintzapen operantearen legeak lirateke korronte honetako ekarpen nagusiak. Thorndikek garatutako hiru legeen artean, efektuaren legea gailentzen da; gertaeren ostean datorren ondorioa atsegina izanez gero, jokabidea errepikatzeko maiztasuna areagotzen dela adierazita (Gil, 2013; Papini, 2012).

Azkenik, Banduraren eskutik, neokonduktismoa delakoa garatu zen (Bandura, 1982). Honi jarraiki, subjektuak ez dauka zertan ondorio atseginik edo desatseginik jaso jarrera aldatzeko edota hau burutzeko, nahikoa da beste pertsona batean ondorio horiek behatu izana (Gil, 2013; González-Pienda, 2008).

Hasieran, teoria psikologiko bezala garatu zena konduktismoa, ostean hezkuntza esparruan eragin handiko eredu bilakatu zen (Coll, 1998; Cortés, 2004), XX. mendeko hezkuntzaren oinarrizko sostengua bihurtuz (Hernández, 2008).

Konduktistentzat ikaskuntza subjektuaren jokabidearen aldaketa da, jokabideak jaso duen erantzun gogoko edo desatseginean oinarrituta (Fonseca eta Niñón, 2011). Beraz, hezkuntza mailan, behaviorismoa, funtsean, edukien transmisio eta erreprodukzioan oinarritzen da (Hernández, 2008) ikaslearen barne prozesuak aintzat hartu gabe, hala nola, afektibitatea, aldagai kognitiboak edota interesa (Carrasco, d.g.; Kohler, 2005tik aipatua). Ikaskuntzaren kontrola, beraz, irakasleak dauka, ezagutzak berak transmitituko dituelarik, ikasleak jasole pasibo hutsak izanda (Gil, 2013; Segura, 2005).

Ondorioz, konduktismoaren aburuz ikaskuntza aurre-ideiekin erlaziorik ez duen erantzunen multzoa izango da. Hau da, informazioa modu mekanikoan ikasiko da irakasleek ikasleei emandako errefortzu edo zigorren bidez (Kohler, 2005). Zigorra arauak edo eskolan ezarritako jokabide moralak hausteagatik ezartzen den ondorio desatsegina da (Valle-Barbosa, Vega-López, Flores-Villavicencio eta Muñoz De La Torre, 2014); ondorioz, subjektuak jokabidea iraungitzea eragiten du ondorio desatsegin horiek saihesteko. Errefortzuak, aldiz, ikasleari ondorio atseginak sorrarazten dizkio eta ondorioz beronek ekintza errepikatzea eragingo du (Castejón et al., 2010; Goñi, 1998). 
Behaviorismoaren baitan lau ondorio mota bereizten dira. Hasteko errefortzu positiboa berriro erreproduzitzea nahi den jokabidearen ostean ematen den saria da, gustuko zerbait ematea alegia (Castejón et al., 2010; Márquez, Díaz eta Cazzato, 2007). Bigarrenik, errefortzu negatiboa ondorio desatsegina ekiditean oinarritzen da, hau da, subjektuarentzat gustukoa ez den zerbait saihesteak jokabidearen maiztasuna areagotzen du (Márquez et al. 2007). Hirugarrenik, zigor positiboa subjektuaren jokabidearen atzetik agertzen den ondorio desatsegina da, jokabidea iraungitzea dakarrena, gustukoa ez den zerbait ematea alegia (Castejón et al., 2010; Gil, 2013). Azkenik, zigor negatiboa gustuko estimulu baten iraungitzean oinarritzen da, hau da, honentzat atsegina den saria kentzean (Coll et al., 2002; Castejón et al., 2010).

Konduktismoaren oinarri diren errefortzuak eta zigorrak aintzat hartuta, portaera aldatzeko teknika desberdinak proposatu izan dira hezkuntzaren pedagogiaren eta psikologiaren baitan (Beltrán, 1998; Trianes eta Gallardo, 2004; Valles, 1998). Hauek helburuen araberakoak dira, jokabidea areagotzeko (1.taula) edo murrizteko (2.taula) helburuekin sortuak.

1.Taula. Jokabidea areagotzen duten teknika konduktistak.

\begin{tabular}{|c|c|}
\hline Moldaketa & $\begin{array}{l}\text { Progresiboki jokabide bat lortzeko erabiltzen da (Gil, 2013). Lortu nahi den } \\
\text { portaera identifikatu eta hau pausu ezberdinetan sinplifikatzen da, pausu } \\
\text { guztiak sarituak izanda (Castejón et al., 2010; Gonzalez-Pineda, 2008). }\end{array}$ \\
\hline Modelatua & $\begin{array}{l}\text { Imitazioan datza (Gil, 2013), erakargarria den subjektu baten edo horrek } \\
\text { jaso duen errefortzua behatzeak eraginda ekintza erreproduzitzea (Coll et } \\
\text { al., 2002). }\end{array}$ \\
\hline Premacken printzipioa & $\begin{array}{l}\text { Indartu nahi den jokabidea burutu ostean, subjektuak gogoko duen } \\
\text { egunerokotasuneko ekintza burutzen uztea da (Castejón et al., 2010). }\end{array}$ \\
\hline Kontingentzia kontratua & $\begin{array}{l}\text { Subjektuak burutu beharreko jarduerak eta horrek izango duen ondorioa } \\
\text { (errefortzu edo zigorra) agertzen den dokumentua da, helduak eta umeak } \\
\text { adostutakoa (Castejón et al., 2010). }\end{array}$ \\
\hline Fitxen ekonomian & $\begin{array}{l}\text { Egutegi baten bidez jokabidearen maiztasuna neurtzen den teknika da. } \\
\text { Helduak eta umeak finkatutako epe amaieran egutegia behatuko da eta } \\
\text { jokabidearen maiztasuna egokia bada umea saritua izango da (Castejón et } \\
\text { al., 2010). }\end{array}$ \\
\hline Hitz goxoak & $\begin{array}{l}\text { Irakasleak ikasleari laudorioak ematean datza, hots, ikasleak atsegin dituen } \\
\text { hitzak adieraztean. Hau da, entzun nahiko dituen hitz horiek bihurtuko dira } \\
\text { sari. Hala ere, errefortzuaren eraginkortasuna bermatzeko goraipamenak } \\
\text { pertsonalizatuak izan behar dira, ikasle bakoitzaren gustuen araberakoa, } \\
\text { alegia (Márquez et al. 2007). }\end{array}$ \\
\hline
\end{tabular}


2.Taula. Jokabidea murrizten duten teknika konduktistak.

\begin{tabular}{ll}
\hline Iraungipena & $\begin{array}{l}\text { Portaeraren ondoren subjektua ez saritzean datza (Gil, 2013). Jokabidea murrizteko } \\
\text { ezinbestekoa da ikasleak errefortzurik ez izatea, helduak jarrera berdina mantenduta } \\
\text { (Castejón et al., 2010). }\end{array}$ \\
\hline $\begin{array}{l}\text { Erantzunen } \\
\text { kostua }\end{array}$ & $\begin{array}{l}\text { Ezabatu nahi den jokabideren aurrean ikasleak duen errefortzua kentzean oinarritzen } \\
\text { da (Márquez et al. 2007). }\end{array}$ \\
\hline Errieta & $\begin{array}{l}\text { Helduak ahotsaren bidez subjektuarentzat desatseginak diren mezuak adierazteari } \\
\text { deritzo (Gil, 2013). }\end{array}$ \\
\hline Asetzea & $\begin{array}{l}\text { Desegokia edo murriztu nahi den jokabidearen etengabeko errepikapena da } \\
\text { (Márquez et al. 2007). }\end{array}$ \\
\hline $\begin{array}{l}\text { Bakartzea } \\
\text { time out }\end{array}$ & $\begin{array}{l}\text { Subjektuak jokabidea egitera bultzatzen duen ingurunetik ateratzean oinarritzen da } \\
\text { (Castejón et al., 2010). Isolatzea era desberdinetan eman daiteke, besteak beste } \\
\text { ikaslea gelatik ateraz, gelako eremu konkretu batera bideratuaz (adibidez } \\
\text { pentsatxokora) edo ikaslea beste gela batera bidaliaz isolatzea (Gil, 2013; Idoiaga, } \\
\text { Otxandio eta Belasko, 2018). }\end{array}$ \\
\hline Praxi positiboa & $\begin{array}{l}\text { Haurrak egindako jokabide desegokia helduak errepikatzea umeak ikusi dezan kaltea } \\
\text { (Gil, 2013). }\end{array}$ \\
\hline
\end{tabular}

\subsection{Zer da konstruktibismoa?}

Konstruktibismoa XX. mendeko 70. hamarkadan sortu zen eta gizakien barne prozesuan oinarritzen den korronte psikologikoa da (Carretero, 1993; González-Pérez eta Criado del Pozo, 2003). Bere aburuz, gizabanakoa ez da inguruko kopia ez eta barne prozesu hutsa eta ondorioz ezagutza bi aldagaien arteko elkarrekintzaren ondorioz garatuko den eraikuntza propioaren emaitza baizik (Díaz eta Hernández, 1999). Behagarriak diren jokabideetan, zein barne prozesuetan oinarritzen den korronte honen barnean lau autore ospetsuk landutako lau azpi-korronte nabarmentzen dira: ikuspegi genetiko-kognitiboa, Piageten eskutik; ikuspegi soziala, Vigotskyk landua; ikaskuntza esanguratsuaren teoria, Ausubelen ekarpena eta aurkikuntza bidezko ikaskuntza, Brunerren bidez (Delval, 2000; Navarro eta Martín, 2010).

Ikuspegi genetiko-kognitiboa Piageten eskutik jasotzen da. Suitzarrak garatutako estadioen eta orekaren teorien bidez subjektuak errealitatea eta eskema mentalak nola eraikitzen eta egituratzen dituen azalduko du. Desoreka mekanismo endogenoetan (barne motibazioan) jarri zuen fokoa berak garatutako teorian ezagutzaren genesia (jatorria), garapena eta egitura kognitiboen finkatzea azaltzeko (Hernández, 2008). Garapen kognitiboa gizakiak mundua ulertzeko eta bertan eragiteko egiten dituen esfortzuen ondorioa da, hau da, Piagetek adimena organismo batek mundura egokitzeko 
egiten duen borroka bezala ulertzen du, non eskema mentalak ezinbestekoak diren (Sanz, 2010). Bestalde, gatazka kognitiboen aurrean ezagutzen oreka lortzeko prozesua asimilazio (ideia berriak eskemetara moldatzea) eta akomodazioaren (eskemak aldatzea ideia berriak barneratzeko) bidez emango da (Gil, 2013).

Vigotskyren eskutik 60 eta 70. hamarkadetan ikuspegi soziala proposatu zen gizartea eta kulturala aintzat hartuta garapenaren prozesu psikologikoak azalduko zituelarik. Ezagutza testuinguru sozial eta kulturaletan subjektuak parte hartze aktiboa duen praktika sozialean oinarritzen da (Vigotsky, 1995; Hernández, 2008-tik). Honenbestez, Vigotskyren arabera, kulturak subjektua determinatzen du, hezkuntza prozesu kulturala izanez ezinbestean (Hernández, 2008; Santrock, 2011).

Ausubelek 1973.urtean ikaskuntza esanguratsuaren teoria plazaratu zuen (Fonseca eta Niñón, 2011), edukiak modu ez arbitrarioan eta aurre-ideiekin erlazionatzen direnean ematen den prozesua azalduaz (Ausubel, 1983). Pedagogoak adierazten duenez, gizakiak ezagutzak errezepzioz bereganatzen ditu, beti ere, hauek esanguratsuak badira (Ausubel, Novak eta Hanesian, 1983).

Azkenik, Brunerrek, 60. hamarkadan, subjektua adimena garatzerako orduan hiru etapa desberdinetatik igarotzen dela azaldu zuen: etapa enatiboa, manipulazioa; etapa ikonikoa, irudikapenak; eta etapa sinbolikoa, abstrakzioa. Gainera, aurkikuntza bidezko ikaskuntza eta aldamioaren teoria bezalako proposamen aski famatuak ere plazaratu zituen Brunerrek bere lanean, jokabideaz gain barne prozesuak ere sakonki landuaz (Woolfolk, 2010). Honenbestez, ikaskuntza prozesu induktiboa dela aldarrikatu zuen non subjektuak esplorazioa eta eskema mentalen bidez ezagutza eraikiko duen (Castejón et al., 2010).

Kontruktibismoan hezkuntzaren helburua hazkuntza pertsonala garatzen duten prozesuak sustatzea da, ikaskuntza esanguratsua, ulerkuntza prozesuaren bidezko barneraketa eta ikasitakoaren funtzionalitatea oinarrizkoak izanik edozein ikaskuntzairakaskuntza prozesutan (Díaz eta Hernández, 1999). Halaber, Piageten lanetan oinarrituz bere lanak burututako Constance Kamiiren (1982) ustez, hezkuntzaren helburua autonomia garatzea da, bakarrik eta era kritiko batez ekiteko gaitasunean oinarritzen dena. Ikuspuntu honen arabera, ikasleak autonomia garatuko du bere ikaskuntza-prozesuaren erantzule bihurtzen baldin bada soilik (Beltrán, 1998; Kohler, 
2005tik aipatua). Hortaz, irakaslearen kezka nagusiena ikaslearen ekimena eta iritzi propioa garatzea izan beharko litzateke (Kamii, 1982).

Konduktismoan ez bezala, ikaskuntza ez da transmisio, barneraketa eta pilaketa hutsean oinarritzen, informazioa interpretatzean, loturak egitean eta berreskuratzean baizik (Clifton,1999; Coll et al., 2002). Hortaz, ikaslea subjektu pasiboa izatetik aktiboa izatera pasatzen da (Gil, 2013). Ikasleak egiturak eraikitzen ditu bere ingurune eta ikaskuntza prozesuaren elkarrekintzarekin. Horregatik, irakasleak egitura horien garapena sustatu behar du, egiturak eskemez osatuta baitaude eta horiek ahalbidetuko die antzeko egoerei aurre egitea (Sampascual, 2001).

Laburbilduz, konstruktibismoan ikaskuntza ezagutza berrien eta aurre-ideien etengabeko antolaketan (Castejón et al., 2010) eta ikasleren parte hartze aktiboan oinarritzen da (Beltrán, 1998; Kohler, 2005tik aipatua), zeinetan ikastea ez den errealitatearen kopia hutsa, pertsona bakoitzak bere errealitatean eraikitzen duen ezagutzaren emaitza baizik (Gil, 2013).

Ikuspuntu hau hertsiki lotua legoke adimen exekutiboren garapena sustatzearekin. Izan ere, adimen exekutiboak bestelako adimenak (adimen kognitiboa, adimen emozionala etab.) antolatzen laguntzen du helburu nagusi gisa ekintza fisiko zein mentala zuzentzea duelarik gure jakintza eta emozioez baliatuaz (Marina eta Pellicer, 2015).

Beraz laburrean, konstruktibismoan oinarritutako baliabideek ikasleen parte hartze aktiboa, garapen globala eta ikaskuntza esanguratsua sustatzea izan beharko lukete xede (Mietzel, 2003), 3. taulan jaso direnek duten gisara.

Beraz, sarrera honetan ikusitakoa laburtuz, XX. mendean konduktismoaren eta konstruktibismoaren agerpenarekin batera hezkuntzan ere beraietan oinarritutako korronte kontrajarriak sortu ziren bakoitzak baliabide edo teknika espezifikoak jorratuaz (Lizaso, Reizabal, Aizpurua eta Norberto, 2013). Korronte haien sorkuntzatik gaur egun arte mende erdi baino gehiago igaro den arren, oraindik, hein handi batean gure hezkuntza sistemako gako dira aipatu berri ditugun baliabide eta teknikak. 
3.Taula. Baliabide konstruktibistak.

\section{Garapen}

hurbileko eremua

(GHE) eta talde lana

Garapen hurbileko eremuak ikaskuntza ekintza sozial eta kulturalean du oinarria (Hernández, 2008). Gilek (2013) adierazten duenez, “Garapen errealaren eta potentzialaren arteko distantzia da” (66.or), hau da, ikasleak bakarrik burutzeko gai ez dena baina beste baten laguntzarekin burutu dezakeena eta ikastera hel daitekeena (Gil, 2013). Beraz talde lanaren oinarri da.

Aldamiatzea $\quad$ Brunerrek proposatutako baliabide honi jarraiki hezitzaileak hezigaiari lagungarriak diren sostengua eta argibideak emango dizkio (Córmack, 2004; Segura, 2005). Dena den, ikaslea gaitasunak eta baliabideak eskuratzen doan heinean, irakaslearen esku hartzea gutxituko da desagertu arte. Hau da, ezagutzak lortzeko ikasleak jasoko duen sostengua progresiboki gutxituko da progresiboa da (Guilar, 2009).

Espiral moduko Brunerren lanei jarraiki, hezkuntza "curriculumak espiralean" eraikitzean datza. Hau curriculuma da, ezagutza-corpus jakin batean gehiago eta hobeto sakonduz joango da ikaslearen garapen kognitiboari dagokion ulermenaren arabera (Guilar, 2009).

Мара

kontzeptualak

Ausubelek proposatutako lanabesa da zein ikaslearen estruktura kognitiboa edo eskemak biltzen dituen irudikapen bisuala den. Bertan, ikasleak dakiena adierazteko eta ezagutzak antolatzeko aukera duen (Lara, 1997).

Galderen bidezko Erantzun zehaztugabeetan oinarritzen da, hau da, erantzun irekiak duten galderetan ikaskuntza Modu honetan, ikasleen gaiarekiko interesa piztu eta erantzuna bilatzeko grina sustatzen da (Esteban, 2000).

Adibide bidezko Kontzeptuak barneratzeko irakasleak adibideak plazaratzean datza. Erreminta honen ikaskuntza bitartez, umeak egoera errealetara hurbilduko dira curriculumeko edukiak ulertzeko ezagutzak eta arrazoitzeko teknikak eskuratuta (Esteban, 2000).

Proiektu bidezko Ikasleengan fokua jartzen duen eta elkarrizketak eta iritzi trukaketak nagusituko ikaskuntza diren teknika pedagogikoa da. Honetan, umeek euren interesak jarraituta, azkenengo emaitza bat lortzeko eta ezagutzak eraikitzeko jarduera desberdinak garatuko dituzte (Sarceda, Seijas, Fernández eta Fouce, 2015).

Arazo bidezko Egunerokotasunean aurki daitezke arazoen ebazpenean oinarritzen den ikaskuntza ikaskuntza proposamena da, zeinetan problema bera aitzakia izango den ikasleen garapen globala sustatzeko (Font, 2004).

Umeen Konstruktibismoan oinarritutako prozesu oro, umeen interesetatik abiatu beharko interesetatik litzateke, interes hauetara konektaturik mantentzeko alternatibak eskaintzea gako abiatzea izango delarik. Horrela, umeen jakiteko grina sustatuko da ikasteko plazera areagotuz (Santivañez, 2004).

Aurkikuntza

bidezko

ikaskuntza

Bereziki Brunerrek landutako baliabide hau ikaskuntza induktiboan datza, hau da, kontzeptuak espezifikotik orokorrera doaz. Teknika honetan, ikaslea da ezagutzak deskubritu eta sortu behar dituena, helduak ez baitio azkenengo emaitza ematen. Dena den, irakasleak erronka ezberdinak (galderak) planteatzen dizkio bere eskema mentalekin lotura egitea ahalbidetuko diena ezagutza horietara heldu dezan (Castejón et al., 2010).

Baina egon al da aldaketarik azken urteotan? Benetan geroz eta konstruktibistagoa den hezkuntza eredu baterantz ahal goaz? Edo konduktismoan oinarritutako teknikak errotuta al ditugu gure ikasgeletan? Itaun guzti hauei erantzuteko asmoz, lan honen xedea gaur egun Euskal Herriko Haur Hezkuntzako ikasgeletan irakasleek beraien 
jarduna korronte konduktista edo konstruktibistetan sustraitzen duten eta bereziki zein baliabide mota (errefortzuetan oinarritutako teknika konduktistak, zigorretan oinarritutako teknika konduktistak edo baliabide konstruktibistak) darabiltzaten aztertzea izango da. Gainera, bai irakasleek lan egiten duten ikastetxe motak (publiko edo pribatuak) eta baita beraien irakasle jardun esperientziak (lanean daramatzaten urteek) metodologia bateko edo besteko teknika gehiago erabiltzera daramatzaten ere aztertzea dugu xede.

\section{Diseinua}

\subsection{Lagina}

Lan honetarako diseinatutako galdetegian Haur Hezkuntzako 117 irakaslek parte hartu zuten, horien artean \% 97,4 emakumezkoak izan zirelarik \% 1.7 gizonezkoa eta \% 0.9 ez bitarra. Nahiz eta emakumezkoen portzentaia nabariki nagusia izan, Haur Hezkuntza bereziki jardun eremu feminizatua izatearen isla da eta beraz lagin adierazgarri kontsideratu zen. Irakasleen bataz besteko adina 35,72 urte izan zen (21 eta 60 urte arteko tartean kokatua) eta DT $=10,49$ delarik. Lan lurraldeari dagokionez \% 47,9k Bizkaian egiten du lan, \% 25,6k Gipuzkoan, \% 19,7k Araban eta \% 6k Nafarroan.

Irakaskuntza munduan daramaten denborari erreparatuz gero, \% 43,6k 5 urte baino gutxiago daramatza lanean, \% 11.10ek 5 eta 10 urte artean, \% 25.60k 10 eta 20 urte artean eta \%19.70ak 20 urte baino gehiago. Halaber, irakasleetako \% 53.80k eskola publikoan egin du lan \% 17.90ek pribatu edo kontzertatuak eta \% 28.20k bietan.

\subsection{Instrumentua}

Ikergaia aztertzeko erabili den instrumentua beren beregi sortutako galdetegia izan da. Galdetegiak hiru atal nagusi ditu: galdera sozio demografikoak, teknika eta baliabide konduktista eta konstruktibista zehatzei buruzko galdera eta irakasleen jardun estrategiei buruzko galdera orokorragoak. Lehenengo atalak, beraz, parte-hartzaileen inguruko informazioa orokorra biltzeko helburua du, hala nola, adina, sexua, bizilekua, lanesperientzia, ibilitako eskolaren izaera (publikoa edo pribatua) eta hezkuntza etapa (Haur Hezkuntza edo Lehen Hezkuntza).

Bigarren atala, ordea, irakasleen ohitura konduktista edo konstruktibisten inguruko 18 item-ez osatua dago, zehazki, konstruktibismoaren inguruko 8 item eta konduktismoari buruzko 10 . 
4.Taula. Irakasleen ohitura konduktistei buruzko itemak eta erreferentzia egiten dieten teknikak.

TEKNIKA EDO BALIABIDE KONDUKTISTAK

\begin{tabular}{cc}
\hline Teknika & Galdera \\
\hline ERREFORTZUAK
\end{tabular}

\begin{tabular}{ll}
\hline & $\begin{array}{l}\text { 4. Zure Haur Hezkuntzako irakasle jardunean ikasleen jokabidea } \\
\text { neurtzeko (jokabide positiboak izan dituztela adierazteko edota } \\
\text { negatiboak izan dituztela) zenbatetan erabiltzen dituzu gometxak eta } \\
\text { gometx positiboei lotutako sariak? }\end{array}$ \\
\hline \multirow{3}{*}{ Premacken printzipioa } & $\begin{array}{l}\text { 8. Zure Haur Hezkuntzako irakasle jardunean ikasleek jarduerak } \\
\text { zuzenak egin dituztenean edota jokabide egokia izan dutenean, } \\
\text { zenbatetan izaten dute klase amaieran gogoko duten ekintza/jolasa } \\
\text { erabakitzeko aukera? }\end{array}$ \\
\hline Hitz goxoak & $\begin{array}{l}\text { 12. Zure Haur Hezkuntzako irakasle jardunean ikasleek jarrera } \\
\text { zuzena izan dutenean zenbateko maiztasunarekin esan dizkiezu hitz } \\
\text { goxoak? }\end{array}$ \\
\hline
\end{tabular}

13. Zure Haur Hezkuntzako irakasle jardunean ikasleek jarduera zail

Moldaketa bat egin behar dutenean zenbatetan zatitzen duzu jarduera atal txikiagoetan eta atal bakoitza lortzen dutenean ikasleei oso ondo egin dutela esan edo saritxo bat eman?

18. Zure Haur Hezkuntzako irakasle jardunean zenbatetan sortzen

Modelatua dituzu maila aurreratua duten ikasleak maila eskasago dutenekin edo jarrera ona dutenak jarrera eskasa dutenekin, batzuk besteen eredu izan daitezen?

\section{ZIGORRAK}

Bakartzea edo time out

2. Zure Haur Hezkuntzako irakasle jardunean zenbateko maiztasunarekin erabiltzen duzu pentsatzeko txokoa?

6. Zure Haur Hezkuntzako irakasle jardunean gelako erritmoa apurtu duenari edo jokabide desegokia izaten dutenei zenbatetan kentzen dizkiezu pribilegioak? (Jolastoki gabe geratu, gustuko jolasik gabe edo antzekoren bat)

10. Zure Haur Hezkuntzako irakasle jardunean zenbateko maiztasunarekin kanporatzen dituzu oso jarrera desegokia duten ikasleak taldetik (korridorera, beste gela batera edo gelako izkina batera bidali)?

15. Zure Haur Hezkuntzako irakasle jardunean zenbatetan erabakitzen duzu jokabide edo jarrera desegokia duen ikasleari

Iraungipena kasurik ez egitea, horrela atentziorik ez jasoaz jokabidea egiteari utz dezan?

Errieta

16. Zure Haur Hezkuntzako irakasle jardunean zenbatetan egiten diezu errieta ikasleei? 
Galderetako bakoitzean teknika konduktista edo baliabide konstruktibista baten deskribapena egiten da (izen teknikorik aipatu gabe) eta irakasle parte-hartzaileei beraien ikasgeletan zenbateko maiztasunarekin erabiltzen duten galdetzen zaie 1-5 likert eskalan (1, inoiz ere ez izanik eta 5 oso sarri). 4. taulan adieraziak ditugu konduktismoari buruzko galderak eta 5. taulan konstruktibismoari buruzkoak bakoitzak erreferentzia egiten dion teknika edo baliabidearen izen teknikoarekin bat.

5.Taula. Irakasleen ohitura konstruktibisten inguruko itemak eta erreferentzia egiten dieten baliabideak.

TEKNIKA EDO BALIABIDE KOSNTRUKTIBISTAK

\begin{tabular}{|c|c|}
\hline Baliabideak & Galdera \\
\hline $\begin{array}{l}\text { Aurkikuntza bidezko } \\
\text { ikaskuntza }\end{array}$ & $\begin{array}{l}\text { 1. Zure Haur Hezkuntzako irakasle jardunean ikasleei zenbateko } \\
\text { maiztasunarekin eman diezaiekezu jorratu nahi duten gaia beraiek } \\
\text { aukeratzeko posibilitatea? }\end{array}$ \\
\hline $\begin{array}{l}\text { Adibide eta galderen bidezko } \\
\text { ikaskuntza }\end{array}$ & $\begin{array}{l}\text { 3. Zure Haur Hezkuntzako irakasle jardunean, zenbatetan hasten } \\
\text { duzu jorratu nahi duzun gaia galdera edo adibideetan oinarrituta, } \\
\text { gaiarekiko ikasleen interesa pizteko eta erantzuna bilatzeko grina } \\
\text { sustatzeko? }\end{array}$ \\
\hline $\begin{array}{l}\text { Garapen Hurbileko Eremua } \\
\text { (GHE) }\end{array}$ & $\begin{array}{l}\text { 5. Zure Haur Hezkuntzako irakasle jardunean zenbateko } \\
\text { maiztasunarekin burutu dezakete haurrek irakaslearen esku- } \\
\text { hartzerik gabeko talde lana, horrela batak bestearengandik } \\
\text { ikasiaz? }\end{array}$ \\
\hline Mapa kontzeptualak & $\begin{array}{l}\text { 7. Zure Haur Hezkuntzako irakasle jardunean eduki berriak } \\
\text { lantzerako unean, zenbateko maiztasunarekin sor ditzakete } \\
\text { muralak edota kontzeptu mapak haien aurre jakintzak } \\
\text { adierazteko? }\end{array}$ \\
\hline Proiektu bidezko ikaskuntza & $\begin{array}{l}\text { 9. Zure Haur Hezkuntzako irakasle jardunean zenbateko } \\
\text { maiztasunarekin egiten dute ikasleek proiektuka edo planteatutako } \\
\text { arazo bati konponbidea bilatzeko metodologiekin lan? }\end{array}$ \\
\hline Umeen interesetatik abiatzea & $\begin{array}{l}\text { 11. Zure Haur Hezkuntzako irakasle jardunean, jarduerak } \\
\text { antolatzerako orduan zenbatetan abia zaitezke umeen interesetatik } \\
\text { edota gelan sortzen den jakin-minetik? }\end{array}$ \\
\hline Espiral moduko curriculuma & $\begin{array}{l}\text { 14. Zure Haur Hezkuntzako irakasle jardunean zenbatetan } \\
\text { lantzen dituzu aurrez aldetik jada ikasleek landu dituzten gaiak } \\
\text { baina orain duten garapen mailara (ezagutza, irudikapena eta } \\
\text { analisia) egokituta? }\end{array}$ \\
\hline Aldamiatzea & $\begin{array}{l}\text { 17. Zure Haur Hezkuntzako irakasle jardunean zenbatetan egiten } \\
\text { duzu ikasleekin "akonpainamendu" lana? Hau da, beraiek zerbait } \\
\text { egiteko gai diren arte lagundu eta gero pixkanaka zure laguntza } \\
\text { kentzen joan beraien kabuz egin dezaten? }\end{array}$ \\
\hline
\end{tabular}


Azkenengo atalean prestakuntzari eta hezkuntzako metodologiari buruzko 4 galdera proposatzen dira. Hauek irakasleek jaso duten prestakuntza ezagutzea eta irakaskuntza metodologiei zenbateko garrantzia ematen dioten jakitea dute helburu. 


\section{Emaitzak}

Ikerketa honetako emaitzak hiru atal nagusitan sailkatuko ditugu, lehenik teknika konduktisten irakasleen erabilera maila aztertuaz, ondoren baliabide konstruktibistena eta azkenik hezkuntza teknikei buruzko balorapen orokorren erantzunak aztertuaz.

Hasteko, korronte konduktistaren barneko tekniketan irakasleek adierazitako erabilpen mailak aztertuko ditugu horretarako lehenik eta behin 6. taulan bildutako jokabidea murrizten (zigorrak) eta areagotzen (errefortzuak) duten tekniken datuak aztertuaz:

6.Taula. Teknika konduktisten erabilpen maila irakaslegoaren esanetan.

\begin{tabular}{|c|c|c|c|c|c|c|}
\hline & & $\begin{array}{l}\text { Inoiz } \\
\text { ere ez }\end{array}$ & Gutxitan & Noizbehinka & Sarri & $\begin{array}{l}\text { Oso } \\
\text { sarri }\end{array}$ \\
\hline \multirow{5}{*}{$\begin{array}{l}\text { Zigorrean } \\
\text { oinarritutako } \\
\text { teknikak }\end{array}$} & $\begin{array}{l}\text { Time out } \\
\text { (Pentsatzeko txokoa) }\end{array}$ & $\% 46,2$ & $\% 24,8$ & $\% 17,9$ & $\% 8,5$ & $\% 2,6$ \\
\hline & $\begin{array}{l}\text { Time out } \\
\text { (Kanporatzea) }\end{array}$ & $\% 37,6$ & $\% 38,5$ & $\% 17,9$ & $\% 6$ & $\% 0$ \\
\hline & Erantzunen kostua & $\% 31,6$ & $\% 32,5$ & $\% 23,1$ & $\% 8,5$ & $\% 4,3$ \\
\hline & Iraungipena & $\% 12,8$ & $\% 20,5$ & $\% 29,9$ & $\% 27,4$ & $\% 9,4$ \\
\hline & Errieta & $\% 2,6$ & $\% 35,9$ & $\% 48,7$ & $\% 10,2$ & $\% 2,6$ \\
\hline \multicolumn{2}{|c|}{$\begin{array}{l}\text { Bataz besteko erabilpena } \\
\text { (zigorrak) }\end{array}$} & $\% 26,2$ & $\% 30,4$ & $\% 27,5$ & $\% 12,1$ & $\% 3,8$ \\
\hline \multirow{5}{*}{$\begin{array}{l}\text { Errefortzuan } \\
\text { oinarritutako } \\
\text { teknikak }\end{array}$} & Fitxen ekonomia & $\% 47$ & $\% 16,3$ & $\% 15,4$ & $\% 12,8$ & $\% 8,5$ \\
\hline & $\begin{array}{l}\text { Premarcken } \\
\text { printzipioa }\end{array}$ & $\% 16,3$ & $\% 11,1$ & $\% 29,9$ & $\% 28,2$ & $\% 14,5$ \\
\hline & Hitz goxoak & $\% 0,9$ & $\% 0,9$ & $\% 5,1$ & $\% 21,3$ & $\% 71,8$ \\
\hline & Moldaketa & $\% 12$ & $\% 9,4$ & $\% 16,2$ & $\% 40,2$ & $\% 22,2$ \\
\hline & Modelatua & $\% 4,3$ & $\% 6,8$ & $\% 26,5$ & $\% 40,2$ & $\% 22,2$ \\
\hline \multicolumn{2}{|c|}{$\begin{array}{l}\text { Bataz besteko erabilpena } \\
\text { (errefortzuak) }\end{array}$} & $\% 16,1$ & $\% 8,9$ & $\% 18,6$ & $\% 28,5$ & $\% 27,8$ \\
\hline \multicolumn{2}{|c|}{$\begin{array}{l}\text { Bataz besteko erabilpena } \\
\text { (teknika konduktistak orokorrean) }\end{array}$} & $\% 21,1$ & $\% 19,7$ & $\% 23,1$ & $\% 20,3$ & $\% 15,8$ \\
\hline
\end{tabular}

Lehenik eta behin, jokabidea murrizten (zigorrak) duten praktiken emaitzak aztertuko dira. Hasteko, time out erabiltzeko joera baieztatzeko bi item plazaratu ziren, pentsatzeko txokoa eta ikasgelatik kanporatzea. Pentsatxokoa irakasleen \% 29k onartzen du noizbehinkatik oso sarrira honetaz baliatzen dela. Gelatik korridorera ateratzeko jaidura ere antzekoa da, \% 23,9k noizbehinkatik oso sarrira erabiltzeko ohitura baitute hezitzaileek. Erantzunaren kostua erabiltzeko joera aurreko praktikena baino apur bat handiagoa da \% 35,9k erabiltzen baitu noizbehinkatik oso sarrira. Azkenik, iraungipena irakasleen \% 66,7k eta errieta \% 61,5ek darabil noizbehinkatik oso sarrira. 
Jokabidea areagotzen duten praktikei erreparatuz gero, errefortzurik erabiliena hitz goxoak dira, izan ere irakasleen \% 98,2k esan du euren ikasleak goresten dituela jokabide baikorra izanez gero. Fitxen ekonomia, ordea, egunerokotasunean joera txikiagoa duen praktika da, irakasleen \% 36,7 noizbehinkatik oso sarrira erabilia. Premarcken printzipioa hezitzaileen \% 72,6k, ia hiru laurdenak, noizbehinkatik oso sarrira praktikan jartzen du. Errefortzuei dagozkien azkenengo teknikei erreparatuz gero, jaidura parekoa da. Hain zuzen ere, moldaketa irakasleen \% 78k noizbehinkatik oso sarrira darabil eta modelatua \% 88,9k. Hortaz, ikasleak jarduera egokia egin ostean saritzeko joera nabarmenki handia da.

Emaitza hauek ikasleen ezaugarrien arabera (publiko, pribatu edo bietan lan eta lan urteak) ezberdinak ziren aztertzeko ANOVA analisiak egin ziren. Hasteko ANOVA frogek adierazi zutenez jardueretako batean ere ez zen ezberdintasunik aurkitu irakasleen lan eremuagatik, hau da irakasleek publiko, pribatu edo bietan lan eginagatik. Irakasleak lanean zeramatzaten urteei erreparatuaz pentsatxoko eta errieta tekniken erabileran ezberdintasunak aurkitu ziren. Pentsatxokoari dagokionez, F $(3,113)=3.58$, $p=0.01$, esanguratsuki ezberdin erabiltzen da jardunean urte desberdinak daramatzaten irakasleen artean. Izan ere bereziki 20 urte baino gehiago daramatzaten irakasleek erabiltzen dute gehien, gero 5 urte baino gutxiago daramatzatenez jarraiki, 5-10 urte daramatzatenak hirugarren eta azkenik 10-20 urte artekoak. 6. taulan Bonferroniren post hoc frogetan ikus dezakegun bezala 20 urtetik gora lanean diharduten irakasleek 5-20 urte artean lanean dihardutenak baino esanguratsuki gehiago darabilte teknika hau eta 5 urtetik behera lanean daudenek 10-20 urte daramatenek baino esanguratsuki gehiago.

Bestalde errietari dagokionez, $\mathrm{F}(3,113)=3.21, p=0.02$, hau ere esanguratsuki ezberdin erabiltzen da jardunean urte desberdinak daramatzaten irakasleen artean. Kasu honetan, justu kontrara, 20 urtetik gora lanean dabiltzanak erabiltzen dute gutxien, gero 5 urte baino gutxiago daramatzatenez jarraiki, 5-10 urte daramatzatenak hirugarren eta azkenik 10-20 urte artekoak. 7. taulan Bonferroniren post hoc frogetan ikus dezakegun bezala 20 urtetik gora lanean diharduten irakasleek 5-20 urte artean lanean dihardutenak baino esanguratsuki gehiago darabilte teknika hau. 
7.Taula. Lan urteen arabera ezberdin erabiltzen diren teknika konduktistak eta berauen post hoc kontrasteak.

\begin{tabular}{|c|c|c|c|c|c|c|c|}
\hline Teknika & Urte lanean & $N$ & $M$ & $S T$ & $F$ & $P$ & $\eta^{2}$ \\
\hline \multirow[t]{4}{*}{ Pentsatxokoa } & $<5$ urte & 51 & 2.18 & 1.14 & \multirow[t]{4}{*}{3.58} & \multirow[t]{4}{*}{$.01 * *$} & \multirow[t]{4}{*}{0.19} \\
\hline & $5-10$ & 13 & 1.92 & 1.32 & & & \\
\hline & $10-20$ & 30 & 1.46 & .73 & & & \\
\hline & $>20$ & 23 & 2.39 & 1.11 & & & \\
\hline \multirow[t]{4}{*}{ Errieta } & $<$ 5urte & 51 & 2.74 & .71 & \multirow[t]{4}{*}{3.21} & \multirow[t]{4}{*}{$.02 *$} & \multirow[t]{4}{*}{0.11} \\
\hline & $5-10$ & 13 & 2.95 & 1.03 & & & \\
\hline & $10-20$ & 30 & 2.97 & .76 & & & \\
\hline & $>20$ & 23 & 2.35 & .64 & & & \\
\hline Teknika & Urteak & & \multicolumn{2}{|c|}{$>20 \mathrm{vs} .5-10$} & \multicolumn{2}{|c|}{ >20vs. $10-20$} & $<5$ vs. $10-20$ \\
\hline Pentsatxokoa & Bonferroni & & \multicolumn{2}{|c|}{$.01 * *$} & \multicolumn{2}{|c|}{$.05^{*}$} & $.05^{*}$ \\
\hline Errieta & Bonferroni & & \multicolumn{2}{|c|}{$.02 *$} & \multicolumn{2}{|c|}{$.05^{*}$} & \\
\hline
\end{tabular}

Teknika konduktisten ostean, irakasleen baliabide konstruktibisten erabilpen mailak aztertu ziren, 8. taulan beha daitezkeelarik emaitza nagusiak.

8.Taula. Baliabide konstruktibisten erabilpen maila irakaslegoaren esanetan.

\begin{tabular}{|c|c|c|c|c|c|}
\hline & $\begin{array}{l}\text { Inoiz ere } \\
\text { ez }\end{array}$ & Gutxitan & Noizbehinka & Sarri & $\begin{array}{l}\text { Oso } \\
\text { sarri }\end{array}$ \\
\hline Aurkikuntza bidezko irakaskuntza & $\% 7,7$ & $\% 19,7$ & $\% 33,3$ & $\% 25,6$ & $\% 13,7$ \\
\hline $\begin{array}{l}\text { Adibide eta galdera bidezko } \\
\text { irakaskuntza }\end{array}$ & $\% 2,6$ & $\% 6$ & $\% 12$ & $\% 38,4$ & $\% 41$ \\
\hline Garapen hurbileko eremua (GHE) & $\% 3,4$ & $\% 8,5$ & $\% 24,8$ & $\% 41,9$ & $\% 21,4$ \\
\hline Mapa kontzeptualak & $\% 12,8$ & $\% 16,3$ & $\% 19,7$ & $\% 35$ & $\% 16,2$ \\
\hline Proiektu bidezko irakaskuntza & $\% 6$ & $\% 12,8$ & $\% 21,4$ & $\% 32,5$ & $\% 27,3$ \\
\hline Umeen interesetatik abiatzea & $\% 0,9$ & $\% 6$ & $\% 33,3$ & $\% 35$ & $\% 24,8$ \\
\hline Espiral moduko curriculuma & $\% 2,6$ & $\% 3,4$ & $\% 30,7$ & $\% 41,9$ & $\% 21,4$ \\
\hline Aldamiatzea & $\% 1,7$ & $\% 1,7$ & $\% 6,8$ & $\% 47$ & $\% 42,8$ \\
\hline Bataz besteko erabilpena & $\% 4,71$ & $\% 9,3$ & $\% 22,75$ & $\% 37,16$ & $\% 26,07$ \\
\hline
\end{tabular}

Konstruktibismoaren baitan bildutako datuen arabera, aurkikuntza bidezko ikaskuntza eta mapa kontzeptualak erabiltzeko ohitura antzekoa da. Brunerrek proposaturiko ikaskuntza (aurkikuntza bidezkoa) kontuan hartuta, \% 72,6k baieztatzen du 
noizbehinkatik oso sarrira erabiltzen duela eta bigarrenaren kasuan, \% 70,9k. Adibide eta galderen bidezko irakaskuntza erabiltzeko jaidura, ordea, handiagoa da; \% 91,4k noizbehinkatik oso sarrira erabiltzen baitu. Bestalde, Vigotskyk proposaturik Garapen Hurbileko Eremua (GHE) \% 88,1ek noizbehinkatik oso sarrira erabiltzen du. Proiektuen bidezko ikaskuntzari dagokionez, \% 81,2k dio noizbehinkatik oso sarrira darabilela. Umeen interesetatik abiatzeari eta espiral curriculumari erreparatuz gero, maiztasuna antzekoa da, zeinetan \% 93,1ek (umeen interesetatik abiatzea) eta \% 94k (espiral curriculuma) erabiltzeko ohitura adierazten den. Azkenengo baliabideari dagokionez, aldamiaia \% 96,6k noizbehinkatik oso sarrira darabil, konstruktibismoren irakaskuntzaren baitan baliabiderik erabiliena izanik.

Kasu honetan ANOVA frogek ez zuten ezberdintasun esanguratsurik aurkitu ez jarduneko ikastetxe motaren arabera ezta irakasleak jardunean zeramatzan urte kopuruaren arabera ere.

Teknika konduktista eta konstruktibisten analisian sakontzeko eta bereziki konduktisten barneko jaiduren ezberdintasuna nabarmenkiago aztertzeko hiru eredu horietako bakoitzean partaideek adierazitako maiztasun mailak kalkulatu ziren. Beraz, 1. irudian eredu metodologiko bakoitza inoiz ere ez, gutxitan, noizbehinka, sarri edo oso sarri zein maiztasunekin erabili izan dela adierazi den behatu ahalko da.

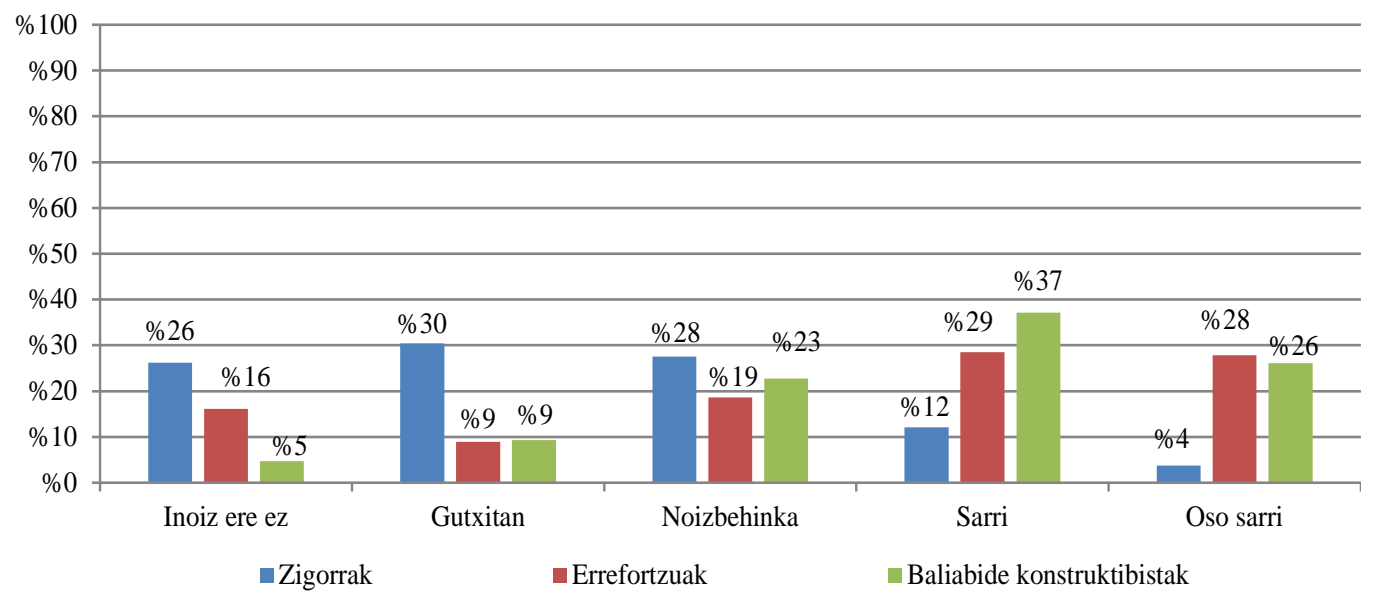

1. Irudia. Eredu ezberdinek maiztasun kategoria bakoitzean adierazi duten erabilpen maila.

Aipatu berri diren taldekatzeen barruan teknika konkretuen erabilera argiago ikuste aldera, zigorrean oinarritutako tekniken maiztasuna kategoria bakoitzean beha daiteke 2 . irudian. Ikus daitekeenez kanporatzea da gutxien erabilitakoa eta iraungipena eta errieta gehien erabilitakoak. 


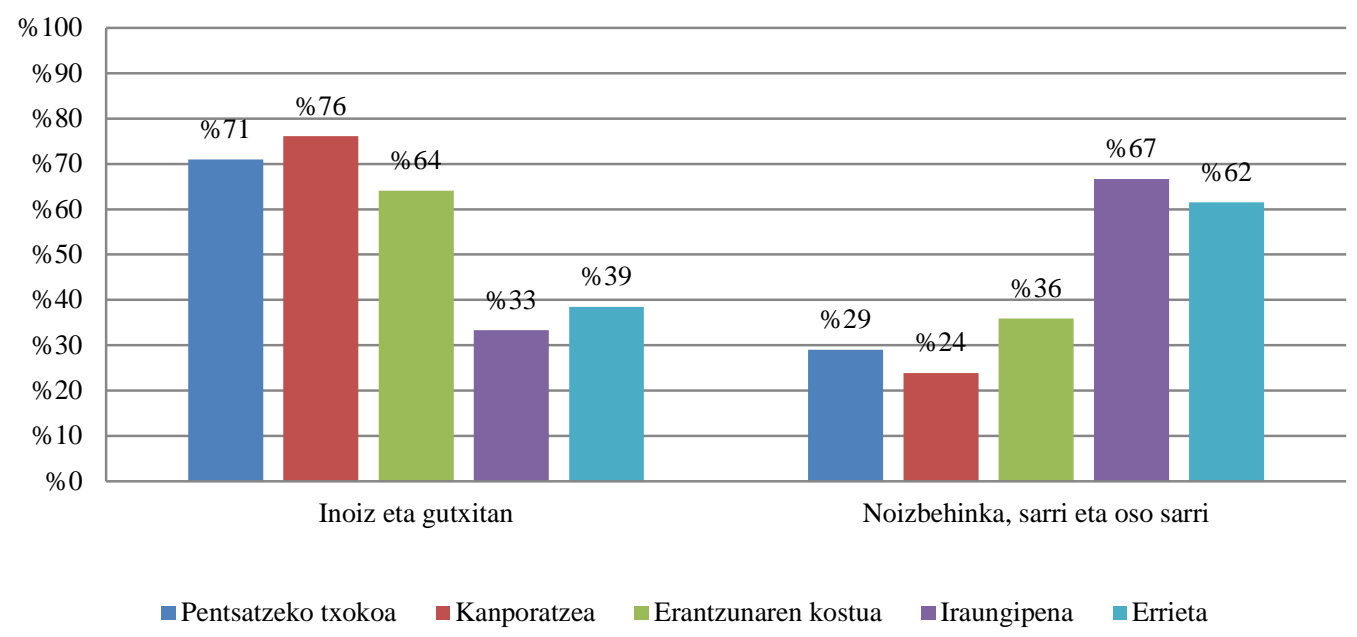

2. Irudia. Zigorrean oinarritutako teknikek maiztasun kategoria bakoitzean adierazi duten erabilpen maila.

Ildo beretik jarraiki, errefortzuetan oinarritutako tekniken maiztasuna kategoria bakoitzean ikus daiteke 3. irudian . Bertan beha daitekeen gisara fitxen ekonomia da gutxien erabiltzen dena eta hitz goxoak, modelatua eta moldaketa gehien erabiltzen direnak.

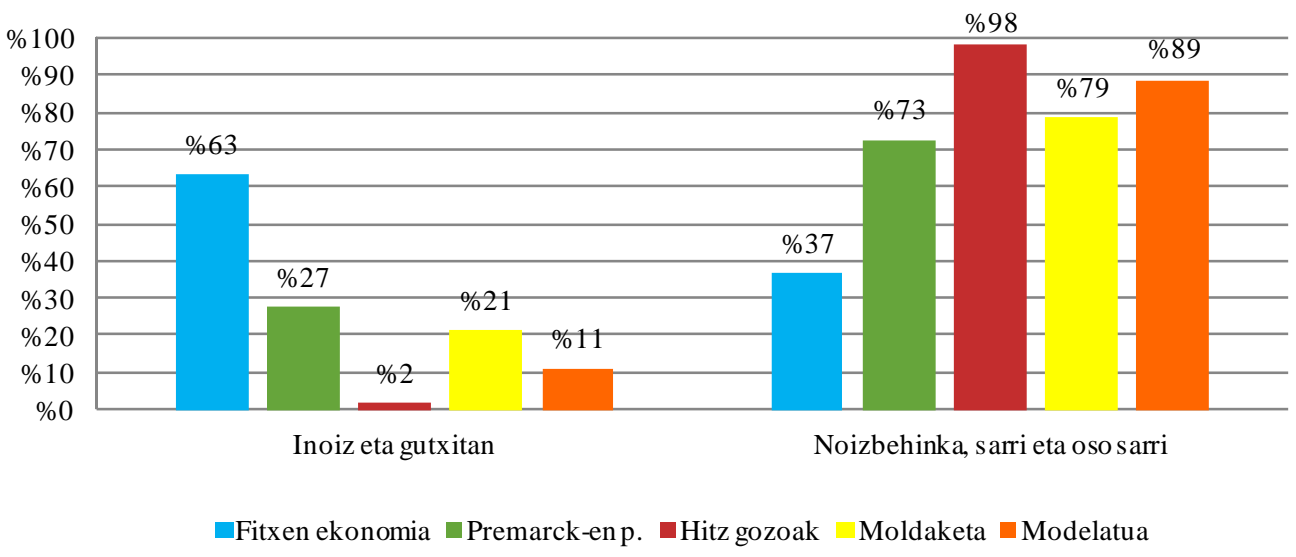

3. Irudia. Errefortzuetan oinarritutako teknikek maiztasun kategoria bakoitzean adierazi duten erabilpen maila.

Azkenik, teknika konstruktibiestetan oinarritutako teknikak maiztasun kategoria bakoitzean ikus daitezke 4. irudian. Guztien artean gutxien erabiltzen direnak mapa kontzeptualak eta aurkikuntza bidezko ikaskuntza dira eta gehien erabiltzen direnak aldamiatzea, espiral moduko curriculuma eta umeen interesetik abiatzea 


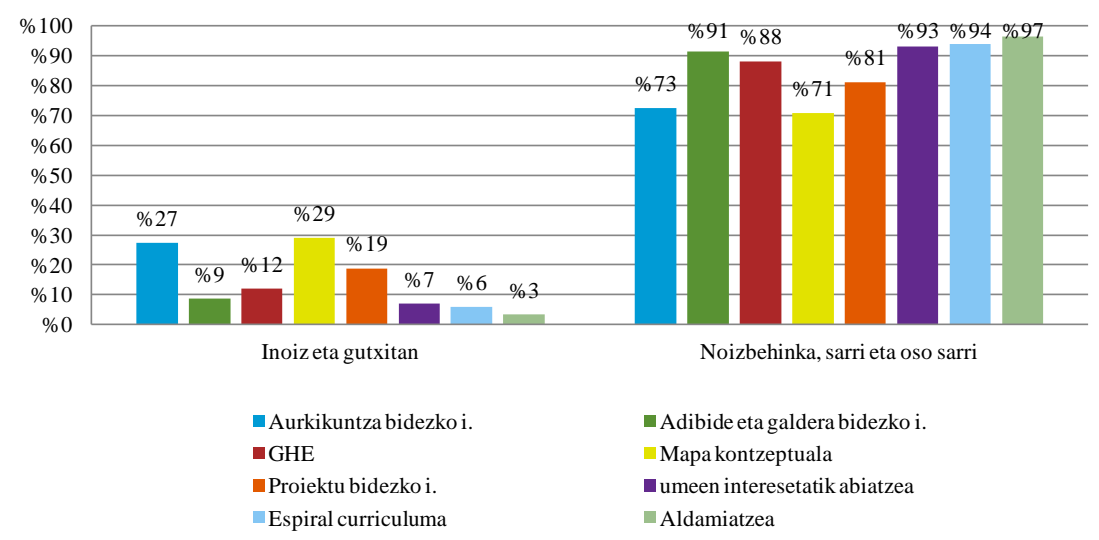

4. Irudia. Teknika konstruktibiestetan oinarritutako teknikek maiztasun kategoria bakoitzean adierazi duten erabilpen maila.Taldekatze honen baitan aurkikuntza bidezko irakaskuntza, adibide eta galdera bidezko irakaskuntza, garapen hurbileko eremua (GHE), mapa kontzeptualak, proiektu bidezko irakaskuntza, umeen interesetatik abiatzea, espiral moduko curriculuma eta aldamiatzea aurki daitezkeelarik.

Bertan ikus daiteke gehiengoak \% 56,6k zigorra gutxitan edo inoiz erabili arren, laurden batek baino gehiagok noizbehinka erabiltzen duela eta \% 15,9k sarri edo oso sarri dio. Baina errefortzuen kasuan maiztasuna aldatzen da, hau ere eredu konduktista izan arren, irakasleen \% 75ek noizbehinkatik oso sarrira erabiltzen baitu. Azkenik, baliabide konstruktibisten erabilera joera ere altua da \% 86k noizbehinka, sarri edo oso sarri erabiltzen baitu.

Euskal Herriko irakasleen irakaskuntza ohiturak behin ezagututa, prestakuntzari eta hezkuntza metodologiei buruzko datuak erreparatzera pasako gara. Aldez aurretik, aipatzekoa da hiru laurdenak baino gehiagok, \% 76,9k, formazioa jaso duela irakaskuntza praktikan dauden, korronte metodologiko eta bakoitzeko irakaste teknika edo baliabideen inguruan. Halere, irakasleen formazio mailan (hasierako eta jarraitua) hezkuntza korronte teoriko edo metodologiko eta bakoitzeko irakaste teknika edo baliabideei zenbateko garrantzia ematen zaien galdetzean \% 46,2k nahiko edo asko ematen zaiola dio, \% 35ek pixka bat eta \% 17,8k gutxi edo ezer ez.

Eskolako antolakuntzan ere datuak antzekoak dira, \% 48,7k dio garrantzia nahiko edo asko ematen ziola, \% 35k pixka bat eta \% 16.3k gutxi edo ezer ez. Maila pertsonalprofesionalean, eredu hauen lanketari irakasleen gehiengoak, \% 87,1ek, garrantzi asko edo nahikoa ematen die, \% 10,3k pixka bat eta soilik \% 2.6k gutxi edo ezer ez. Emaitza guzti hauek 9. taulan ikus ditzakegularik zehatz-mehatz. 
9.Taula. Prestakuntza eta metodologien garrantzia maila irakaslegoaren esanetan.

\begin{tabular}{|c|c|c|c|c|c|}
\hline & Ezer ez & Gutxi & Pixka bat & Nahiko & Asko \\
\hline $\begin{array}{l}\text { Irakasleen formazioan } \\
\text { garrantzia eman }\end{array}$ & $\% 5,1$ & $\% 13,7$ & $\% 35$ & $\% 30,8$ & $\% 15,4$ \\
\hline $\begin{array}{l}\text { Eskolako antolakuntzan } \\
\text { garrantzia eman }\end{array}$ & $\% 6$ & $\% 10,3$ & $\% 35$ & \% 35 & $\% 13,7$ \\
\hline $\begin{array}{l}\text { Irakasle gisa norberak } \\
\text { garrantzia eman }\end{array}$ & $\% 0,9$ & $\% 1,7$ & $\% 10,3$ & $\% 41,8$ & $\% 45,3$ \\
\hline Bataz besteko erabilpena & $\% 4$ & $\% 8,56$ & $\% 26,77$ & $\% 35,87$ & $\% 24,8$ \\
\hline
\end{tabular}

Kasu hauetan ere ANOVA frogek ez zuten ezberdintasun esanguratsurik aurkitu ez jarduneko ikastetxe motaren arabera ezta irakasleak jardunean zeramatzan urte kopuruaren arabera ere.

\section{Eztabaida}

Ikerketa honetan irakasleek beraien jardunean darabiltzaten teknika ezberdinak aztertu nahi izan dira. Funtsean, gaur egungo haur hezkuntzako geletan korronte konduktista edo konstruktibista gailentzen den ikertzea izan delarik gure xedea, eskuratutako datu esanguratsuenetik hainbat ekarpen egin direlarik.

Hasteko, konduktismoaren erabilpen nabaria aurkitu dugu irakasleen \% 78,87k darabilelarik. Nahiz eta errefortzu eta zigorren jaidura oso desberdina izan, errefortzuak zigorrak baino askoz maila handiagoan erabiltzen baitira.

Zigorrari dagokionez, 2018an burututako antzeko ikerketa batean, eskoletan praktiketan ari ziren Haur Hezkuntzako Graduko ikasleei galdetu zitzaien geletan zigorrik aplikatzen zen beha zezaten (Idoiaga, Otxandiano eta Belasko, 2018). Bertan zigorren aplikazioa oso altua zela egiaztatu zen (ikasleen \% 98k behatu zuelarik) gure datuetan baino \% 24,2 gehiago. Nahiz eta bi azterlanak makro-ikerketak ez izan eta lagin espezifiko batzuetara mugatuak egon, aldea nabaria da. Halere, bi urte soilik pasa direla aintzat hartuta zaila deritzogu zigorren eboluzioak horrelako aldaketa nabarmena izatea. Oraingoan zuzenean irakasleei zigorra aplikatzen duten galdetu zaie, beraz, baliteke onarpen edo desirabilitate soziala medio irakasleek benetan aplikatzen dituzten zigor tasa baino baxuagoa aipatu izana. Dena den, emaitzak erkatuz alde deigarriak sumatzen dira, esate baterako, une honetan erantzunaren kostua \% 13,9 eta taldetik kanporatze \% 
20,5 tekniken erabilerak gora egin du. Nahiz eta pentsatxokoaren erabilerak behera egin duen, \% 16,5 alegia.

Pentsatxokoari buruzko azkenengo datu hori benetan geletako errealitatearen isla balitz, hau da pentsatxokoaren erabilera benetan jaitsi balitz, onarpen sozialagatik bada ere, hezkuntzan aurrerapauso bat bezala ulertu daiteke. Izan ere, Umearen eskubideei buruzko Nazioarteko Konbentzioaren esanetan teknika honek umeen osasun mentala urratu dezake (Morawska eta Sanders, 2001 eta UNDOC, 2009; Benavente eta Cove, 2015tik aipatua), baita, epe luzean ikaslearen jarrera txarrera joatea bultzatu ere (Solter, 2000; Benavente eta Cove, 2015tik aipatua); kasu gehienetan haur hezkuntzako ikasleek beraien jokabidearen inguruan hausnartzeko gaitasunik ez dutela ahaztu gabe (Readdick eta Chapman, 2000; Benavente eta Cove, 2015tik aipatua). Halere, pentsatxokoaren erabileran jardun urte tarteka adierazitako emaitzek beste kezka bat ere sor dezakete zeren eta teknika hau gehien erabiltzen dutenak lanean 20 urte baino gehiago daramatzatenak diren arren, beraz “eskola zaharreko” kontsidera daitezkeenak, harrigarriki gazteenak, lanean 5 urte baino gutxiago daramatzatenak dira bigarren erabiltzaile nagusiak. Hau horrela izanik agian gradu formazioan aipatu berri ditugun pentsatxokoaren kalteei buruzko informazio zehatzagoa eskaini beharko litzatekeela ondoriozta dezakegu. Interesgarriki, errietarekin justu kontrakoa gertatzen da 20 urte baino gehiago lanean dabiltzan irakasleek gutxiago erabiltzen dutelarik, honek ere hausnartzera eraman gaitzake eta aipatu berri dugun “eskola zahar” horretatik ere ikasteko hainbat gauza ditugula adierazi.

Errefortzuei erreparatuz gero, hezkuntzaren historian ikasleen jokabideak aldatzeko tresnarik erabilienetarikoak izan dira (Castejón et al., 2010) eta gure emaitzetan ere teknika oso erabiliak dira (\% 83,9). Halere, ezin dezakegu ahaztu nahiz eta umeengan aplikazioa ezberdina izan, errefortzuak zigorrak bezala konduktismoan oinarritzen direla (Castejón et al., 2010). Gainera, errefortzuek eragin zuzena dute motibazioan, hau ikaskuntzan ezinbesteko aldagaia izanik (Castejón et al., 2010). Errefortzuak erabilita umearen kanpo-motibazioa suspertzen da, hots, ikasleak gauzatuko dituen ekintza eta jarrera guztiak ondorio atseginak jasotzera bideratuko dira eta ez ikaskuntzak dakarren prozesua ezagutzera. Kanpo motibazio hori barne motibazioa edo motibazio intrintsekoaren ordez gailentzen da, ikasleak berezko duen hezkuntzarekiko interesa eta motibazioa indargabetuz, honi gehiegizko justifikazioaren efektua deritzolarik (Gaviria, Tourón eta González, 1994; Navarro eta Quijano, 2003). Halaber, errefortzu positiboen 
artean hitz goxoen erabilera gailentzen da, \% 99,1ak darabil eta. Dena den, goraipamenak nola, zeintzuk eta noiz erabiltzen diren kontuan hartu beharreko aldagaiak dira (Flores, Ivette eta Guillén, 2014). Izan ere, “zein polita zaren” edo "burubelarri ibili ostean lortu duzu” biak hitz goxo kontsidera daitezke baina batean fokua pertsonaren ezaugarrietan jartzea eta bestean berriz burututako lanean edo ikaskuntza prozesuan, motibazioan ondorio guztiz ezberdinak eraginez. Beraz, lehenengo laudorioak ikasleak irakaslearen oniritzia jasotzera zedarritzera darama, ikaskuntza dakarren onurak erreparatu gabe eta hau da bereziki saihestu beharrezkoa (Woolfolk, 2010). Beraz, garrantzitsua litzateke hitz goxo horiek benetan feedbacka ematen duten edo ez aztertzea, hala balitz metodologia konstruktibisten (Segura, 2015) edota humanisten baitan kokatu ahalko liratekeelako, baina ez izatekotan beraien erabilera motibaziorako kontrajarria izan daitekeelako (Segura, 2015).

Orain arte aztertutako datuetan teknika konduktisten erabilera jorratu da, nahiz eta irakasleen jardunean baliabide konstruktibistek ere erabilera zabala duten, gutxi gorabehera errefortzuen pare. Honek Kamiik (1982) Piageten lanetan oinarrituz esan zuen gisara autonomia moralaren garapena ahalbidetzera bidera ditzake gaur egungo ikasleak. Baita, motibazio intrintsekoa suspertzera ere, haurra bere hezkuntzaprozesuaren gidari eta erantzule delarik (Kamii, 1982).

Konstruktibismoaren inguruan bildutako datuak sakonago aztertuaz Brunerrek proposatutako baliabideen nagusitasuna sumatzen da, zehazki, aldamiatzea eta espiral curriculumarena. Modu honetan, irakasleak euren jardunean haurren ikaskuntzaren bide-laguntzaileak bilakatzen dira ikasleei beraiei ikaskuntza-prozesuan autonomia emango dieten tresnak sortzea ahalbidetuz (Segura, 2005). Bestalde, teknika hauen erabilera maila erreala hau baldin bada irakasleak jada ez lirateke ezagutzen edukitzaile bakarrak, haurrek beraien esperientzietatik eta ingurunetik jasotako informazioaren bitartez adimena garatzea bilatuko baita (Hernández, 2008). Hortaz, korronte psikologiko honen nagusitasunak hezkuntzak gaur egungo errealitatearen beharretara egokitzeko erronka islatzen du, ikaslearen parte-hartzea balioesten eta oroimenezko ikaskuntza alboratzen duelarik. Era berean, adimen exekutiboan oinarrituta lan egiteko dagoen joeraren isla ere izan liteke, non emozio eta kognizioak kontutan hartzen diren. Emaitzak hauek parte-hartzaileek jasotako prestakuntzaren ondorioa izan litezke, irakasleen hiru laurdenak baino gehiagok korronte metodologikoen inguruan formazioa jaso dutela baitiote. Gainera orohar bai irakasleek beraiek, bai eskolek eta baita 
irakasleen formazioen (hasierako eta jarraia) arduradunek eredu metodologikoen eta berauen aplikapenen lanketari garrantzia ematen dietela dirudi.

Ikerketa honek baditu zenbait muga ere. Izan ere, planteamendua bera zurruna izan daiteke korronte bateko ala besteko teknikak hautatu behar direlako. Hau da, praktikan dikotomia hau artifizial xamarra izan daiteke korronte eta tekniken uztarketa lar kontuan hartzen ez dituelako. Horregatik etorkizuneko iker lerro gisa interesgarri litzateke teknika ezberdinen erabilpen maiztasunetik haratago berauek erabiltzean jasotako zailtasun egoerei buruz ere galdetzea. Edota baita teknika eta metodologia ezberdinak zertarako erabiltzen diren planteatzea eta horren analisiak burutzea. Xede hauetarako emaitza kuantitatibo hauen analisi kualitatiboekin uztartzea oso gomendagarria litzatekeelarik.

Beraz eta esandako guztia azken ondorioetan bilduz, ikerlan honek gaur egungo ikasgeletan teknika konduktista eta konstruktibistak uztartzen direla adierazi du. Alde batetik, konduktismoan oinarritutako zigor teknikak irakasleek geroz eta gutxiago erabiltzen dituztela ikusi da baina aldi berean errefortzuen erabilerak indartsu darrai oraindik. Teknika hauek ikasleak alienatzera eraman litzatekeen heinean, helduak ezarritakoa hertsiki bete behar izateagatik, ikasleen pentsamendu kritikoa garatzea mugatzen du. Beraz, hezkuntzan motibazio intrintsekoa bultzatzeko tekniken garrantzia indartu beharko litzateke, besteak beste irakasleek jada darabiltzaten teknika konstruktibisten erabilera bultzatuaz. Beraz, Euskal Herriko irakasleen erronka konstruktibismoaren erabilera gailentzearekin batera, euren jardunerako tresnak garatzea litzateke. Horretarako Haur Hezkuntzako irakasleei motibazioari, teknika konstruktibistei eta errefortzuen kalteei buruzko prestakuntza eskaintzea berebizikoa litzatekeelarik bai graduko formakuntzan eta baita formakuntza jarraian ere. Horrek etorkizunean Euskal Herriko irakaskuntza sisteman jada egiten ari diren aurrerapausoak bermatzea ahalbidetuko bailuke, konstruktibismoa gailenduaz eta kalitatezko hezkuntza sustatuaz. 


\section{Bibliografia}

Ausubel, D. (1983). Teoría del aprendizaje significativo. Fascículos de CEIF, 1, 1-10.

Ausubel, D.P., Novak, J.D. eta Hanesian, H. (1983). Psicología Educativa: un punto de vista cognoscitivo. México: Trillas.

Bandura, A.(1982). Teoría del aprendizaje social. Madrid: Espasa-Calpe.

Beltrán, J. (1998). Procesos, estrategias y técnicas de aprendizaje. Madrid: Síntesis.

Beltrán, J. eta Bueno, J. A. (1995). Psicología de la educación. Barcelona: Editorial Boixareu Universitaria.

Benavente, M. eta Cova, F. (2015). Análisis sobre las ventajas y desventajas del uso del Tiempo Fuera como técnica de manejo conductual en niños preescolares. Revista Gaceta de Psiquiatría Universitaría, 11(1), 61-66.

Bueno, J. A. eta Castanedo, C. (1998). Psicología de la educación aplicada. Madrid: CCS.

Carretero, M. (1993). Constructivismo y Educación. Zaragoza: Edelvives.

Castejón, J., González, C., Gilar, R. eta Miñano, P. (2010). Psicología de la Educación. Alicante: Editorial Club Universitario.

Clifton, B. (1999). La psicologia del aprendizaje desde el enfoque constructivista. Revista Latinoamericana de psicologia, 31(3), 463-475.

Coll, C. (1998). Psicología de la Educación. Barcelona: Edhasa.

Coll, C., Palacios, J. eta Marchesi, Á. (2002). Desarrollo psicológico y Educación II. Psicología de la Educación Escolar. Madrid: Alianza.

Córmack, M. (2004). Estrategias de aprendizaje y enseñanza en la educaión del menor de 6 años. Acción Pedagógica, 13(2), 154-161.

Cortés, S. (2004). Enfoque conductista. Contextos, estudios de humanidades y ciencias sociales, 12, 127-130.

Delval, J. (2000). Aprender en la vida y en la escuela. Madrid: Morata.

Díaz, A.F. eta Hernández, R. G. (1999). Constructvismo y aprendizaje significativo. En A. F. Díaz eta R. G. Hernandez (EDK.) Estrategias docentes para un aprendizaje significativo (13 33orr.). México: MC Graw.

Esteban, M. (2000). El diseño de entornos de aprendizaje constructivista. Revista de Educación a distancia, (6). 
Flores, B., Ivette, N. eta Guillén, D.M. (2014). Reconocimiento y motivación en el aula: resaltando las fortalezas de los estudiantes. CuidArte "El Arte del Cuidado", 3 (6), 20-25.

Fonseca, H. eta Niñón, M. (2011). Teorías del aprendizaje y modelos educativos. Salud, Arte y Cuidado, 4, 71-93.

Font, A (2004). Líneas maestras del aprendizaje por problemas. Revista Interuniversitarioa de Formación del Profesorado, 18(1),79-95.

Gaviria, J.L., Tourón, J. eta González, M.C. (1994). La orientación motivacional intrínseco-extrínseca en el aulavalidación de un instrumento. Revista de pedagogía, 46 (1), 35-51.

Gil, P. (2013). Hezkuntzaren Psikologia: teoria eta praktika. Leioa: UPV/EHU.

González-Pérez, J. eta Criado del Pozo, M. J. (2003). Psicología de la Educación para una enseñanza práctica. Madrid: CCS.

González-Pienda, J. A. (2008). Manual de Psicología de la Educación. Madrid: Pirámide.

Goñi, A. (1998). Psicología de la educación sociopersonal. Madrid: Fundamentos.

Guilar, M. (2009). Las ideas de Bruner: "de la revolución cognitiva" a la "revolución cultural". Educere, 13(44), 235-241.

Hernández, G. (2008). Los constructivismos y sus aplicaciones para la educación. Perfiles educativos, 30(122), 38-77.

Idoiaga, N., Otxandiano, A. eta Belasko, M. (2018). Zigorra haur hezkuntzako geletan: egoeraren analisia eta ondorioak. Ikastorratza, e-Revista de didáctica, 21, 1.

Juaristi, L.P. (2003). Gizarte ikerketarako teknikak. Teoria eta adibideak. Leioa: Euskal Herriko Unibertsitatearen Argitalpen Zerbitzua.

Kamii, C. (1982). La autonomía como objetivo de la educación: implicaciones de la teoría de Piaget. Infancia y aprendizaje, 5(18), 3-32.

Kohler, J. (2005). Importancia de las estrategias de enseñanza y el plan curricular. Liberabit, 11, 25-34.

Lara, J. (1997). Estrategias para un aprendizaje significativo-constructivista. Enseñanza, 15, 29-50.

Lizaso, I., Reizabal, L., Aizpurua, A. eta Norberto, M. (2013). Garapenaren psikologiaren ikuspegi historikoa: diziplinaren sorrera eta finkapena.Uztaro, 87, 71-90. 
Marina, J. A. eta Pellicer, C. (2015). La inteligencia que aprende. Madrid: Santillana.

Márquez, J., Díaz, J. eta Cazzato, S. (2007). La disciplina escolar: aportes de la teorías psicológicas. Revista de Artes y Humanidades UNICA, 8 (18), 126-148.

Mietzel, G. (2003). Claves de la Psicología. Herder Editorial.

Navarro, J. I. eta Martín, C. (2010). Psicología de la educación para docentes. Madrid: Pirámide.

Navarro Cid, J. eta Quijano de Arana, S. D. D. (2003). Dinámica no lineal en la motivación en el trabajo: propuesta de un modelo y resultados preliminares. Psicothema, 15 (4), 643-649.

Ortega, J. (2001). La motivación en educación infantil con medios de comunicación y tecnologías multimedia. Publicaciones, 3, 133-152.

Papini, M. (2012). Evolución del aprendizaje: fundamentos metateóricos a un siglo de la tésis de Thorndike. Apuntes de Psicologia, 30 (1-3), 265-274.

Pellón, R. (2013). Watson, Skinner y algunas disputas dentro del conductismo. Revista Colombiana de Psicología, 22, 389-399.

Sampascual, G. (2001). Psicología de la educación. Tomo I. Madrid: UNED.

Santiváñez, V. (2004). La didáctica, el constructivismo y su aplicación en el aula. Cultura, XVIII (18), 137-148

Santrock, J. W. (2011). Psicología de la Educación. México: McGraw Hill. (4 Edición).

Sanz, L. J. (2010). Psicología evolutiva y de la educación. Madrid: CEDE.

Sarceda, M.C., Seijas, S.M., Fernández, V. eta Fouce, D. (2015). El trabajo por proyectos en Educación Infantil: aproximación teórica y práctica. Revista Latinoamericana de Educación Infantil, 4(3), 159-176.

Segura, M. (2005). El ambiente y la disciplina escolar desde el conductismos y el constructivismo. Actualidades Investigativas en Educacion, 5, 1-18.

Segura, F. J. (2015). Uso del feedback como estrategia de evaluación: aportes desde un enfoque socioconstructivista. Revista Electrónica "Actualidades Investigativas en Educación", 15(1), 1-24.

Trianes, M. V. eta Gallardo, J. A. (coord.) (2004). Psicología de la Educación y del desarrollo en contextos escolares. Madrid: Pirámide.

Valle-Barbosa, M., Vega-López, M., Flores-Villavicencio, M. eta Muñoz-De la Torre, A. (2014). Los castigos escolares utilizados como técnica para mantener la 
disciplina en las escuelas mexicanas a partir del siglo XIX. Revista de educación y desarrollo, 28, 61-68.

Vallés, A. (1988). Modificación de la conducta problemática del alumno. Técnicas y programas. Alcoy: Marfil.

Woolfolk, A. (2010). Psicología Educativa. México: Pearson, Prentice-Hall. 